\title{
Forcible Protection of Nationals Abroad and Humanitarian Intervention: Might or Right?
}

\author{
Professor Solomon E. Salako ${ }^{1}$ \\ ${ }^{1}$ Department of Law and Archbishop Desmond Tutu Centre for War and Peace Studies, Liverpool Hope \\ University, Liverpool, United Kingdom \\ Correspondence: Professor Solomon E. Salako, Department of Law and Archbishop Desmond Tutu Centre for \\ War and Peace Studies, Liverpool Hope University, Liverpool, United Kingdom. E-mail: salakos@hope.ac.uk
}

\author{
Received: May 5, 2016 Accepted: June 2, 2016 Online Published: August 25, 2016 \\ doi:10.5539/ilr.v5n1p152 URL: http://dx.doi.org/10.5539/ilr.v5n1p152
}

\begin{abstract}
The forcible protection of nationals abroad (a rescue mission) and humanitarian intervention (intervention of one state or a group of states in a territorial state where there is a threat or actual loss of life, forced migration or gross violation of human rights and which, at times, involves government replacement or nation building) are different doctrines which, in functional terms, overlap.

Since 1945, the ius ad bellum (the rules of international law governing the legality of the use of force) are stated in Articles 2(4) and 51 of the UN Charter. Since the end of the Cold War in 1989, some states and an increasing number of scholars have attempted to discard the prohibition of the use of force and to create new exceptions such as preventive war, pro-democratic intervention and unilateral intervention.

The objects of this article are: (i) to assess critically the attempt to drive a horse and a coach through the provisions of Articles 2(4) and 51 of the UN Charter; (ii) to show that a legal regime laid down by the UN Charter which is founded on a genuine ius contra bellum (law against war) remains unaffected; (iii) to show that the transmogrification of 'political sovereignty' to 'popular sovereignty' and the use of human rights as justifications for humanitarian intervention can be construed as a subterfuge; and (iv) to analyse the economic, political and strategic reasons for humanitarian intervention and to show how stretching international law to justify a 'right' is simply replaced by 'might'
\end{abstract}

Keywords: international law, protection of nationals, humanitarian intervention, might or right

\section{Introduction}

The violence within liberalism of the Lockean type in which liberty and warfare (civil and international wars) are bound together subsists today. In his Second Treatise of Civil Government, Locke drew a distinction between the maintenance of 'peace, safety or security' of a society and the exercise of moral virtue (Locke, 1946). He went on in the defence of the colonial enterprise, by stating that God had given the world to men in common, 'and nobody has originally a private dominion exclusive of the rest of mankind in any of them as they are thus in a state of nature' (Note 1).

At the time Locke was writing in the seventeenth century and up to the end of the nineteenth century there was what was known as the 'standard of civilisation' argument by which peoples were classified as either "civilised" or "uncivilised" (Ayoob, 2002). Echoes of this 'standard of civilisation' approach reverberate in the "sovereignty as responsibility' approach which adds 'respect for a minimum standard of human rights' as an essential attribute of sovereignty and renders states that are less than democratic, according to this standard, a target of humanitarian intervention by powerful states in disregard of a world order based on the Westphalian Peace.

The 'world order' created after the Thirty Years' War in 1648 was based on the principles of state sovereignty and inherent equality of sovereign states regardless of their power or domestic system. In spite of the fact that the Peace was concluded in Europe without the involvement of most of the other continents and civilisations, those principles are accepted by the international community as binding on all states (Kissinger, 2015). The problem, however, is that since the Westphalian Peace of 1648, the concept of political sovereignty has been on the defensive; and, what is more, democracy, whether liberal or illiberal, and its adjunct 'human rights' have been proffered as rationales of intervention by a state or group of states in a target state under the banners of 
protection of nationals abroad and humanitarian intervention.

From the outset, the term 'humanitarian intervention' must not be confused with diplomatic intercession or non-coercive intervention (Chesterman, 2001). Humanitarian intervention must also be distinguished from 'protection of nationals abroad'. While the forcible protection of nationals abroad is a rescue operation limited to the intervention itself, humanitarian intervention is the use of force by a state or a group of states aimed at preventing egregious violations of human rights of individuals other than its own citizens; and often involves the replacement of government and nation building (Note 2). In functional terms, there is an overlap because intervention on grounds of protecting nationals abroad is often supplemented or supplanted by humanitarian justifications such as justifications on the grounds of democracy and/or human rights or, in the new parlance, 'responsibility to protect', as we shall see in section 3 below.

Historically, the term 'humanitarian intervention', which came into use in the nineteenth century (Note 3), has its classical origins in the just war idea in the Middle Ages. The just war idea formulated by the Church Fathers Ambrose (AD 340-397), Augustine (AD 354-430) and Aquinas (AD 1224/6-74) - was elaborated by Hugo Grotius (1583 - 1645) who in his seminal text De Iure Belli ac Pacis presented a systematisation of the practice and authority of the ius belli (the law of war) (Note 4).

The protection of nationals abroad means different things to different people. According to Grotius, a sovereign was justified in resorting to self-help to protect his citizens (Note 5). In a similar vein, Wolff asserted that men who make a nation were as individuals bound to the whole for promoting the common good and the whole was bound to the individual to provide 'things which are required as a competency for life, peace and security' (Note 6). Although the protection of nationals was not expressly mentioned by Wolff, it is implied that such a protection is required 'as a competency for life, peace and security', and he believed that the state was obliged to protect its nationals abroad. For Vattel, 'whoever offends the state ... declares himself its enemy, and exposes himself to be justly punished for it'. But Vattel's endorsement of the protection of nationals abroad was tempered by the doctrine of sovereignty. He argued that 'we should not only refrain from usurping the territory of others; we should also abstain from every act contrary to the rights of the sovereign' (Note 7).

In this article, we shall discuss the following themes:

(i) Humanitarian intervention and the prohibition of the use of force in the UN Charter;

(ii) The attempts to limit the scope of the prohibition of the use of force;

(iii) Forcible protection of nationals abroad;

(iv) Humanitarian Intervention, Pro-Democratic Intervention and Responsibility to Protect;

(v) The Bush Doctrine; and

(vi) An evaluation of the economic, political and strategic reasons for humanitarian intervention with a view to showing how stretching international law to justify a 'right' is simply replaced by 'might'.

Bearing in mind the evolution of the doctrine of protection of nationals abroad and humanitarian intervention and the principles of sovereignty of states and the inherent equality of states (discussed above), we proceed to the first theme - the prohibition of the use of force under the UN Charter.

\section{Humanitarian Intervention and the Prohibition of the Use of Force Under the UN Charter}

Sixteen centuries since Augustine's days, the use of force in international law is now governed by Articles 2(4) and 51 of the UN Charter. But first we must note Article 1(1) of the UN Charter which states that the purposes of the United Nations are:

"To maintain international peace and security, and to that end to take collective measures for the prevention and removal of threats to peace and for the suppression of acts of aggression or other breaches of the peace, and to bring about by peaceful measures and in conformity with the principles of justice and international law adjustment or settlement of international disputes or situations which might lead to a breach of the peace."

The rules of international law governing the legality of war are discussed with two Latin names: ius ad bellum (the rules of international law governing the legality of the use of force by states) and ius in bello (the rules by which international law regulates the actual conduct of hostilities once the use of force has begun). The two principal sources of ius ad bellum since 1945 have been Articles 2(4) and 51 of the UN Charter. Article 2(4) states:

"All members should refrain from the threat or use of force against the territorial integrity or political 
independence of any state, or in any other manner inconsistent with the purposes of the United Nations."

The prohibition in Article 2(4) above must be read conjunctively with Article 51 of the UN Charter, the relevant part of which states:

"Nothing in the present Charter shall impair the inherent right of individuals or collective self-defence, if an armed attack occurs against a member of the United Nations, until the Security Council has taken measures necessary to maintain international peace and security."

Article 2(4) prohibits the use of force against the territorial integrity or political independence of another state, irrespective of whether the use of force amounts to war. Although Article 2(4) avoids the term 'war', its prohibition transcends war and covers forcible measures short of war. As expounded by the International Court of Justice in the 1996 Advisory Opinion on the Legality of the threat or use of nuclear weapons:

"The notion of 'threat' and 'use' of force under Article 2, paragraph 4 of the Charter stand together in the sense that if the use of force in a given case is illegal - for whatever reason - the threat to use force will likewise be illegal" (Note 8).

The Court in the case concerning Military and Paramilitary Activities Against Nicaragua noted that "whether the response to the [armed] attack is lawful depends on observance of the criteria of the necessity and proportionality of the measures taken in self-defence" (Note 9). In the Oil Platforms case (Note 10), the criteria of necessity and proportionality in the context of self-defence were examined. One aspect of these criteria is the 'nature' of the target of the force used avowedly in self-defence. In order to establish that it was legally justified in attacking Iranian oil platforms in the exercise of its right of self-defence, the United States had to show that the attacks had been made upon it for which Iran was responsible and that those attacks were of such a 'nature' as to be qualified as 'armed attacks' within the meaning of Article 51 of the Charter (Note 11). In that case, the Court found that the actions of the United States could not be justified as measures necessary to protect its security in 'the light of international law on the use of force' (Note 12).

The exercise of individual or collective self-defence is subjected to two procedural checks: (i) recourse to self-defence must be reported to the Security Council with the least possible delay, and (ii) the exercise of the right is terminated with the adoption of the appropriate measures by the Security Council. Article 2(4) must also be read conjunctively with Article 2(3) of the Charter which reads:

"All members shall settle international disputes by peaceful means in such manner that international peace and justice are not endangered."

\section{Attempts to Limit the Scope of the Prohibition of the Use of Force}

Since the entry into force of the UN Charter, several attempts have been made to drive a horse and a coach through the provisions of Articles 2(4) and 51 of the UN Charter discussed above. Some writers rely on reviving the just war idea outlined above in contemporary international law while other writers argue that the UN Charter is a convention of constitutional nature and that allowance should be made for political considerations in interpreting Article 2(4) (Corten, 2012), and these considerations have been used to justify 'preventive war', 'anticipatory self-defence', 'unilateral intervention' and 'pro-democratic intervention'. Brownlie reminds us that:

"[t]he doctrine [of humanitarian intervention] was inherently vague and it is open to abuse since only powerful states could undertake measures of this sort, and when military operations were justified as 'humanitarian intervention', this was only one of the several characterisations offered and circumstances frequently indicated the presence of selfish motives" (Note 13).

Writers, like Brownlie and Chesterman, adopt the Restrictive Approach of interpreting Articles 2(4) and 51 of the UN Charter while writers affiliated to or are citizens of the United States such as D'Amato, Reisman and Tesón adopt what is known as the Extensive Approach (D’Amato, 1996, Reisman, 1990, and Tesón, 1996).

Proponents of the Restrictive Approach contend that although the General Treaty for the Renunciation of War as an Instrument of National Policy known as the Kellog-Briand Pact 1928 (named after the American Secretary of State and the French Foreign Minister) signed in Paris prohibited war, war remained lawful. So, when the Charter of the United Nations was adopted in 1945, one of its aims was to redress the shortcomings of the ruling Kellog-Briand Pact by making Article 2(4) the pivot of the present day ius ad bellum. They argue that though Article 2(4) avoids the term 'war', its prohibition transcends war and covers forcible measures short of war. They also argue that in the adoption of the UN Charter in 1945, the exercise of both forms of self-defence (individual and collective) is subjected to a double procedural check: (i) self-defence must be reported to the 
Security Council with the least possible delay, and (ii) the exercise of the right is terminated with the adoption of the appropriate measures.

Advocates of the Extensive Approach adopt several devices either to nullify the provisions of Articles 2(4) and 51 of the UN Charter or to drive a horse and a coach through these provisions. Their arguments are as follows:

\subsection{Protection of Nationals Abroad}

Two arguments are pressed into service to justify the protection of nationals abroad. The first argument is that the protection of nationals abroad does not run foul of Article 2(4) of the UN Charter since 'such emergency does not impair the territorial integrity or political independence of a state, it merely rescues nationals from a danger which the territorial state cannot or will not prevent' (Wingfield, 2000).

It is worthy of note that in the Corfu Channel case (Note 14), the United Kingdom argued that a minesweeping operation in the Albanian territory threatened neither the territorial integrity nor the political independence of Albania and that Albania suffered neither territorial loss nor loss to any part of its independence. In rejecting this line of argument, the International Court of Justice stated:

"The Court cannot accept this line of defence. The Court can only regard the alleged right of intervention as a policy of force, such as has, in the past given right to serious abuses and such as cannot, whatever be the present defects in international organisation, find a place in international law" (Note 15).

'Territorial integrity', Oppenheim argues, 'especially where coupled with 'political independence' is synonymous with territorial inviolability' (Oppenheim, 1952). For Brownlie, the terms 'territorial integrity' and 'political independence' were included in Article 2(4) of the UN Charter in order 'to give specific guarantees to small states, rather than to have a restrictive effect. This is now the dominant view" (Note 16). Higgins, while agreeing with Brownlie and Oppenheim, that the 'use of force, no matter how brief, limited, or transitory do violate state's territorial integrity' opines that the Caroline or Webster formula, though suggested a long time ago, still has operational relevance and is an appropriate guide to conduct (Higgins, 1995).

The second argument rests on the words 'inherent right of self-defence in the event of an armed attack' in Article 51 of the Charter. It is suggested that it is feasible to argue that the defence of nationals whether within or without the territorial jurisdiction of a state is in effect the defence of the state. We shall discuss the Caroline case or Webster formula under anticipatory self-defence, and to this we now turn.

\subsection{Anticipatory Self-Defence}

It is argued that Article 51 of the UN Charter failed to abrogate the pre-existing customary right of self-defence which allowed anticipatory action. The authority cited in support of this proposition is the Caroline case (Jennings, 1938).

During the revolt in Canada in 1837, preparation for subversive action against British authorities were made in the United States territory. In particular, a United States arsenal was looted to obtain arms. The United States took proper measures on its soil to ensure that there was no breach of duty that could be alleged against its authorities. However, the rebels in Canada were receiving arms supplied by the Steamer Caroline from ports in the United States. A British force from Canada entered the United States' territory, seized the Caroline in New York, and destroyed her.

Great Britain justified the action on the grounds of 'self-defence' and 'self-preservation' but United States arrested one of the British forces involved, named Alexander McLeod, and charged him with murder and arson. Great Britain protested and the formulation by the American Secretary of State, Daniel Webster, of the conditions upon which the invasion of a neighbouring country could be accepted as a justification for the concept of self-defence became known as the Caroline or Webster formula. The conditions enunciated by Webster are that there must be a 'necessity of self-defence, instant, overwhelming and leaving no choice of means, and no moment of deliberation' and 'the action taken must not be unreasonable or excessive' and 'limited by the necessity and kept within it'. The dispute ended with an apology by Great Britain. Although the Caroline case has been invoked on several occasions and in particular was pleaded at Nuremberg and Tokyo on behalf of the German and Japanese war criminals, it was rejected by the International Tribunals. As Jennings observed, 'in the Caroline case self-defence was changed from a political exercise to a legal doctrine and self-defence implies a prior attack which self-preservation does not' (Note 17).

It is submitted that if the threat could be contained or turned aside by calling an emergency meeting of the Security Council, the criteria of Caroline will not apply. Self-defence provisions of Article 51 of the UN Charter 
come into effect 'if an armed attack occurs'. It could not be used to justify the blockade of Cuba in 1962. In that incident, the United States did not attempt to justify the naval quarantine imposed on Cuba aimed at impeding the delivery of offensive weapons and materials by Soviet Union to Cuba as an exercise of self-defence because there was no indication that the United States was confronted by an 'imminent threat of an armed attack', and this implied that the action came under the category of 'preservative' rather than 'pre-emptive' self-defence (Ruys, 2010). Similarly, Israel's airstrike against the Osiraq reactor in Iraq in 1981 could not be considered an act of self-defence because 'there was no armed attack on the US in 1962 anymore than there was on Israel in 1981' (Note 18).

\subsection{Pro-Democratic Intervention}

It will suffice to say for the time being that proponents of pro-democratic intervention argue that the term 'political sovereignty' is anachronistic when applied to undemocratic governments and should be replaced by 'popular sovereignty' vested in individual citizens of a state (Reisman, 1990). This means that unilateral intervention to support or restore democracy does not violate state sovereignty and, by implication, the UN Charter. We shall discuss pro-democratic intervention in full later in this excursus.

\subsection{The Reagan and Bush Doctrines}

The Reagan Doctrine asserting that the right to use force to vindicate democracy - just as the earlier Brezhnev Doctrine to vindicate socialism - has been rejected. The Reagan Doctrine states that legitimate government depends on the content of the governed and its respect for the right of the citizen and that a government is not legitimate simply because it has independent rulers (Henkin, 1991). The Bush Doctrine is a rationalisation of the US and the 'coalition of the willing' in Iraq 2003 (Bush, 2010). We shall discuss this later in this excursus. But, first, we must tease out the political, economic and strategic interests that drove the military interventions from the Suez Canal Crisis in 1956 to the Iraq War in 2003, and to these we now turn.

\section{Forcible Protection of Nationals Abroad}

The protection of nationals abroad, according to Brownlie, is 'the exercise of the right of self-preservation, the right of self-defence, as one of several justifiable forms of intervention, or as actions justified in terms of necessity' (Note 19). Brownlie is averse to the protection of nationals as a justification for the use of force for four reasons. First, few governments that have invoked anticipatory self-defence have been consistent in their practice. Second, there have been other political objectives without which the risk would not have been worth taking. Brownlie opines that the Israeli claim that anticipatory action was taken against Egypt in 1967 cannot be assessed without an investigation of the assurances given by the United States to Israel and Egypt respectively. Third, the Webster formula or the Caroline case defines 'necessity' in terms of itself without specifying the criteria for ascertaining the presence or lack of it.

Fourth, the United States practice, as we shall see from the incidents we are discussing on the protection of nationals involving the US, has drawn a certain blurring of the distinction between self-defence and reprisals. And, what is more, there is considerable difference between 'self-defence' and 'self-preservation'. Self-defence presupposes an attack while 'self-preservation has no such limit and would serve to cloak with legality any act of violence on the part of a state' (Note 20). The notable incidents of forcible protection of nationals abroad are as follows:

\subsection{Suez Canal Crisis 1956}

The crisis following the nationalisation of the Suez Canal by President Gamal Abdel Nasser of Egypt in July 1956 is a neat illustration, in one incident, of the economic, political and geopolitical or geostrategic reasons for humanitarian intervention or for the protection of nationals abroad as defined in the Introduction.

The Suez Canal Company (La Campagnie Universale due Canal Maritime de Suez) was formed by statutes dated 5 January 1856. The company has, as one of its objects, the construction and operation of a canal through the Isthmus of Suez to link the Mediterranean Sea with the Red Sea. On 17 November 1869 the Suez Canal was opened to navigation. The Convention of Constantinople was signed on 29 October 1888 between Great Britain, Germany, Austria, Hungary, Spain, Italy, the Netherlands, Russia and Turkey. Article 1 of the Convention provided in part:

"The Suez Maritime Canal shall always be free and open, in time of war as in time of peace, to every vessel of commerce and of war, without distinction of flag. Consequently, the High Contracting Parties agree not in any way to interfere with, the free use of the Canal, in time of war as in time of peace."

On 19 October 1936 the governments of the United Kingdom and Egypt concluded a treaty providing, inter alia, 
for the stationing of British forces in the canal zone subject to review in 20 years' time. Article 8 of the treaty commenced:

"In view of the fact that the Suez Canal, whilst being an integral part of Egypt, is a universal means of communication as also an essential means of communication between the different parts of the British empire..."

The 1936 Treaty was replaced by an Anglo-Egyptian Agreement of 19 October 1954 which provided for the withdrawal of British forces from Egypt subject to a right of temporary return to the Suez base if an armed attack took place against Arab States, including Egypt, or Turkey. The Suez Canal was nationalised by President Nasser on 26 July 1956 by a law promulgated by the Council of State of Egypt (Law No. 285) which transferred to the State all its funds, rights and compensation. Shareholders were to be compensated at a value deemed appropriate by the Paris bourse immediately prior to the date of the law.

At the time of nationalisation of the Suez Canal, there were few British servicemen left in Egypt. The canal was not blockaded; there was still freedom of movement of ships in the canal. It is true that of the seventy million tons of oil passing through the canal, sixty million tons went to Western Europe, two-thirds of the Western oil supply (Pearson, 2003). But the fact remains that the United States had its own oil reserves and was averse to the colonial sentiments that prevailed in Britain which eventually led to the joint invasion of Egypt by Britain, France and Israel. Sir Anthony Eden (later Lord Avon), the then Prime Minster of Britain and a former Foreign Secretary, was renowned for his diplomatic skills as Foreign Secretary. But Eden's likening of Nasser to Hitler, the assumed exaggeration of the menace posed by Nasser and the parallels drawn with dictators of the 1930s led to a crisis with divergent interests (Kyle, 1992). The traditional imperial pretension of ruling the Middle East, Eden's misreading of the role of Europe in foreign affairs (the World War II not only destroyed Nazi Germany but also the role of Europe in foreign affairs) and the fact that Britain was indebted to the United States to the tune of $\$ 3.75$ billion influenced not only the invasion of Egypt by Britain, France and Israel, but also the cessation of hostilities. Eden (the then Prime Minister) and Harold Macmillan (later to succeed Eden as the Prime Minister after the Suez blunder) in drawing parallels with dictators of the 1930s ignored the counsel of prudence that:

"Historical parallels often sound trite in failing to take account of the complexities of individual circumstances. The supposed 'lessons of history' invite simplistic analysis which adds very little to genuine understanding' (Note 21).

The legality of the invasion of Egypt in October 1956 must now be broached taking cognisance of the political, economic and geopolitical/geostrategic reasons outlined above.

The legal issues raised by the combined intervention of Britain, France and Israel in Egypt are (i) whether the act of nationalisation itself violated the Convention of Constantinople of 1888, and (ii) the legality of armed intervention (Merston, 1988).

The first question, whether the nationalisation of the Suez Canal was itself a breach of international law must be answered in the negative. Sir Gerald Fitzmaurice, the Legal Adviser to Britain's Foreign Office, expressed the view that though the Egyptian Government committed a number of illegality, none of them amounted to a direct breach of the Suez Canal Convention.

As for the legality of an armed intervention, the Conservative Government of the period searched for a casus belli. The Foreign Secretary, Selwyn Lloyd, as late as the Cabinet Meeting of 14 August 1956, acknowledged that the use of force prohibited by Article 2(4) of the UN Charter was only permissible under Article 51 of the Charter in only three situations:

(i) Actual self-defence by a State against an armed attack on its territory or on its forces or warships;

(ii) Collective self-defence by a group of States against an attack under (i) above; and

(iii) Collective action under United Nations authority (Merston, 1988).

In the debates in the British Parliament, Lord Kilmuir, the Lord Chancellor, in the House of Lords, rested his case for intervention on three grounds. The first was the protection of nationals abroad: that intervention was justified when there was an 'imminent danger of injury to nationals abroad' through the failure or inability of the territorial sovereign to protect them. Fitzmaurice, in his own view, was sure that the Suez Canal Company employees were free to leave their post provided that they gave required notice and were under threat of imprisonment only if they sought to leave in breach of contract. Hence, the substratum of Lord Kilmuir's first ground of 'imminent danger of injury to nationals abroad' evaporated. 
The second ground by Lord Kilmuir was the danger to shipping in the canal and the danger to the enormously valuable installations. It was found as a fact that there was a free passage of ships through the canal The third ground, according to Lord Kilmuir, was that the right to self-defence was not at all limited to the circumstances specified in Article 51 of the UN Charter outlined above. Nor did the Charter restrict self-defence to cases where the attack had actually been launched. This is trite jurisprudence since self-defence presupposes an armed attack. The plea of vital interest as one of the main justifications for war in the past was, indeed, the very one the UN Charter intended to exclude as a basis for armed intervention in another country under Article 2, paragraphs 3 and 4 of the Charter.

The period 4 to 14 October 1956 was a crucial period during the Suez Canal Crisis: Eden had given up hope on the United States' support for an Anglo-French invasion of Egypt because the Cold War interests of the United States did not coincide with Britain's. The United States perceived the Middle East as a vital link of defence against the Soviet Union and were fearful that Anglo-French military intervention would unite the Arab world in passionate hostility and untold cost to Western interests. When Eden saw that he could not influence the President of the United States, Dwight Eisenhower, and his Secretary of State, Foster Dulles, he embraced the Sèvres plan which entailed the Israeli invasion of Egypt on 29 October 1956, the issuing of ultimatum on the $30^{\text {th }}$, an Anglo-French bombardment on $31^{\text {st }}$, followed by an invasion on 5 November and an amphibious landing. The Attorney-General, Sir Reginald Manningham-Butler, the Solicitor-General, Sir Henry Hilton-Foster, and Sir Gerald Fitzmaurice, the legal adviser to the Foreign Office, were not consulted and would not have supported that travesty of international law.

Military operations were brought to an end not only by the Resolution of the United States at the United Nations on which Britain was outvoted sixty-five to five in a call for ceasefire and withdrawal of British, French and Israeli forces from Egypt but also by economic imperatives. The Sterling was depreciating in value at an alarming rate and a Government propped up by a generous loan of $\$ 3.75$ billion by the United States could not continue to resist its benefactors (Note 22).

\subsection{Lebanon 1958}

On 15 July 1958, 2,000 Marines landed in Beirut 'to protect American lives' and by their presence there to encourage the Lebanese government in defence of Lebanese sovereignty and integrity. Some commentators have criticised the action of the US on political grounds but few registered legal objection because of the existence of a formal invitation from Lebanon's recognised government (Wingfield and Meyen, 2002).

\subsection{Congo (1960 and 1964) and (1996 and 1998)}

In 1960, Belgium intervened after the independence of Congo. Mutinying Congolese troops committed atrocities on Belgian residents and other nationals. There was a constitutional crisis: the democratically elected Prime Minister of Congo, Patrice Lumumba, was sacked by the President, Joseph Kasavubu. Lumumba called for help from the Soviet Union. Belgian paratroopers, supported by the United States, entered the country purportedly to protect and evacuate Belgian nationals and foreigners. Lumumba, regarded as an ally of the Soviet Union by the United States, was captured by the Belgian paratroopers and executed. France, UK and Italy all expressed sympathy for what the French labelled 'an intervention on humanitarian grounds'. The Soviet Union and several other states including Tunisia and Poland condemned the intervention as an outright aggression.

In 1964, Belgium and the United Kingdom launched another intervention in the Congo, after rebel forces fighting the Tshombe government seized control of the cities of Stanleyville and Paulis. In a few weeks, thirty-five foreign residents were killed, including nineteen Belgians and two Americans. The intervention was justified on two grounds: (i) the consent of legitimate Congolese authorities, and (ii) the responsibility to protect their nationals abroad. The Soviet Union, Yugoslavia and twenty-one African and Asian states accused Belgium and the US of 'premeditated aggression'. Many states argued that the Tshombe government was not a 'legal' government of Congo, but a puppet regime imposed by force. The so-called 'rescue operation' was described as a pretext for intervening in Congo politics (McNemar, 1971).

The aversion of Western powers to communism and leftist ideology influenced their support for President Joseph Mobutu who later on plundered the Treasury of Congo before he fled in May 1997 when a coalition of Rwandan and Ugandan armies allied with some long-time opposition figures led by Laurent Dèsirè Kabila marched on Kinshasa, Zaire (as Congo was then known). (The name was later changed into the Democratic Republic of Congo (DRC).) The first civil war fought from 1996 to 1997 was to drive Mobutu out of Zaire. However, a few months later, President Kabila, fearing that the Tutsi led Rwandan army who were running his army were plotting a coup in order to give the presidency to a Tutsi who would report to the President of Rwanda, asked Rwandan army officers and Ugandan troops to leave. 
The second civil war, started in 1998 by militia sponsored by Rwanda and Uganda, was to take over the mineral resources of the country. The DRC has $80 \%$ of world's coltan which is a major source of tantalus used in the fabrication of electronic components in computers and mobile phones. The insatiable global demand for coltan and other minerals and the trade between foreigners and their collaborators - the Congolese warlords - drive the civil wars in Congo (Mantz, 2008, and Smith, 2011). (The DRC is the world's largest producer of cobalt ore and a major producer of copper and industrial diamonds. More than $30 \%$ of the world's diamond reserves are in the DRC.)

In the Case concerning armed activities on the territory of Congo (Democratic Republic of Congo v Uganda) (Note 23), the DRC in the light of the events outlined above from 1996 to 1998 submitted that following the withdrawal of Ugandan troops from its territory, Uganda had continued to provide arms to ethnic groups confronting one another in the territory of the DRC and that these paramilitary activities amounted to aggression. Uganda submitted that Ugandan troops were first on the territory of the DRC on the invitation of President Kabila and when Kabila broke off his alliances with Rwanda and Uganda and established new alliances with Chad, that there were cross-border attacks on Uganda by Kabila's new allies and that Uganda responded in self-defence. The International Court of Justice found that although Uganda claimed that it acted in self-defence, there was no evidence that the 'armed attacks' came from the DRC. The Court therefore found that the legal and factual exercise of a right of self-defence by Uganda against the DRC were not present (Note 24). The Court found also that Uganda was responsible for acts of looting, plundering and exploitation of the DRC's natural resources committed by its troops in the territory of the DRC, for violating its obligation of vigilance in regard to these acts and for failing to comply with its obligations under Article 43 of the Hague Regulations of 1905 as an occupying power in respect of all acts of looting, plundering and exploitation of natural resources in occupied territory (Note 25).

\subsection{Dominican Republic 1965}

The US has relied on the protection of nationals' doctrine on several occasions after the Stanleyville operation (section 4.3 above).

The situation in the Dominican Republic in 1965 was more complex than in Congo (1960 and 1964), discussed above, because a military junta which ousted President Bosch in 1963 was itself ousted in 1965, law and order completely broke down, and the de facto rulers of the country in April 1965 informed the US Embassy in Santo Domingo, the capital of the Dominican Republic, that they could no longer protect American lives. 500 US troops were sent to Santo Domingo to evacuate the nationals of the US and other countries. If the US troops had left after accomplishing their rescue mission, then this would have been a genuine protection of nationals abroad. In Congo, the paratroopers left once they had completed their rescue mission; in the Dominican Republic (1965), the build-up of military personnel rose to 20,000 for the purpose of policing the capital. The original justification for intervention - the protection of nationals abroad - then became vacuous and a quasi-humanitarian justification - the maintenance of law and order to enable the Organisation of American States to act collectively - was postulated. The real reason for the intervention was the United States' aversion to communism (Lillich, 1967; Wingfield and Meyen, 2002).

\subsection{The Entebbe Raid 1976}

The Entebbe raid was considered by scholars as the clearest example of the protection of nationals abroad doctrine. In that incident, terrorists hijacked a French aircraft and diverted it to the Uganda airport of Entebbe where non-Israeli passengers were released. An Israeli aerial commando stormed the plane, resulting in the killing of the hijackers as well as a small number of hostages. Several Ugandan soldiers were also wounded and about ten Ugandan aircraft were destroyed. Israel relied on the right of a state to take military action to protect its nationals in mortal danger. The right was allegedly recognised in international law and regulated by the criteria in the Caroline case discussed above. Higgins cited with approval the criteria enunciated by Professor Sir Humphrey Waldock (later Judge Waldock) that (i) the threat of injury was imminent; (ii) there was a failure or inability on the part of the territorial sovereign to protect them; and (iii) the measures of protection were strictly confined to the object of protecting their nationals against injury (Waldock, 1952). She concluded that the criteria were met in the Entebbe situation 'because President Idi Amin [of Uganda] far from endeavouring to negotiate the safe release of the passengers, provided further arms for the hijackers and ominously separated Jewish from non-Jewish passengers' (Note 26).

\subsection{Iran 1980}

On 4 November 1979, armed Muslim fundamentalist students stormed the US Embassy in Tehran and took more than five dozen diplomats and consular staff, Marines and other US citizens hostage. Their demand was that the 
former Shah of Iran who was then receiving medical treatment in the United States should be extradited to Iran to face criminal trial, a demand the United States rejected. An attempt to impose sanctions on Iran under Articles 39 and 41 of the UN Charter was vetoed by the Soviet Union. The US instituted proceedings against Iran in the International Court of Justice in Case Concerning United States Diplomatic and Consular Staff in Tehran (US v Tehran) (Provisional Measures) (Note 27), requesting, inter alia, the immediate release of all the hostages and the Court to adjudge and declare that the Government of Iran in tolerating, encouraging and failing to prevent and punish the conduct described, violated Articles 2(3), 2(4) and 33 of the UN Charter. Iran did not appear.

While the matter was before the Court, an attempt by the US to rescue nationals was frustrated by sandstorm and mechanical and navigational difficulties (Wingfield and Meyen, 2002). The Court, in the Provisional Orders, did not pronounce on the legality of the US action but declared the action inappropriate for it to have been launched when the matter was before the Court.

\subsection{Grenada 1983}

On 25 October 1983, US troops landed in Grenada where a violent coup d'etat had been staged by radical Marxist opponents of the leftist Maurice Bishop regime. The newly constituted Revolutionary Military Council was deposed after three days of fighting. US troops withdrew by 15 December leaving a small number of US and Caribbean support personnel on the island.

This was not presented by the US as humanitarian intervention but the echoes of pro-democratic intervention reverberate (Chesterman, 2001).

\subsection{Panama 1989}

President G H W Bush Snr ordered the invasion of Panama a few weeks after the fall of the Berlin Wall in November 1989. On 20 December 1989, US troops began an operation to overthrow the government of Panama and capture its head of state, General Manuel Noriega. The four reasons for the intervention called 'Operation Just Cause' are: (i) to safeguard the lives of Americans, (ii) to defend democracy in Panama, (iii) to combat drug trafficking, and (iv) to protect the integrity of the Panama Treaty (Henkin, 1991).

The US invasion of Panama is a clear violation of Article 2(4) of the UN Charter because invading a country to settle political differences is a use of force contrary to the purposes of the United Nations to maintain peace and security in Article 1(1) of its Charter.

The US explicitly invoked Article 51 of the UN Charter that it acted in self-defence. There is no exception that permits the use of force to topple a regime even where lives are threatened since the United States itself in 1979, acting with the United Nations, condemned the invasion of Cambodia by Vietnamese forces to depose a regime notoriously guilty of the genocide of one million people and refused to recognise the regime imposed by the Vietnamese government.

Abducting Noriega from Panama in order to prosecute him in the United States for drug trafficking is a violation of international law. In the Eichmann case, Israeli officials entered Argentina anonymously in 1960 and abducted Adolf Eichmann, a major architect of the Holocaust. Argentina objected. Israel confessed its violation of international law, apologised and still tried and executed Eichmann (Arendt, 1963).

It has been suggested that defending the Panama Canal as a justification for the invasion must have been intended humorously (Note 28). The Panama Canal Treaties gave United States the right to protect the canal against an armed attack by an external power and not to use force to defend the canal against attack by forces of the Government of Panama. There are parallels between the invasion of Panama by the United States and the invasion of Egypt in 1956 by the British, French and Israel forces but, as hinted above, 'historical parallels often sound trite in failing to take account of individual circumstances. The supposed 'lessons of history' invite simplistic analysis which adds very little to genuine understanding' (Note 29). The Suez invasion was a post-colonial adventure while the invasion of Panama was a pro-democratic intervention. Finally, it was not the protection of nationals that won the support of academics for the invasion of Panama but the pro-democratic rationale (D'Amato,1990).

\section{Humanitarian Intervention, Pro-Democratic Intervention and Responsibility to Protect}

There are two types of intervention: (i) intervention by a state to protect its nationals abroad (a 'rescue mission'), and (ii) intervention to protect the human rights of individuals against violations by their own governments. The two arguments in support of humanitarian intervention are (i) limited interventionism, and (ii) broad interventionism.

Limited interventionism is the thesis that humanitarian intervention is justifiable in cases of genocide, mass 
murder and enslavement and there is a 'responsibility to protect'. Broad interventionism is the thesis that humanitarian intervention is justifiable in cases of serious human rights violations. Tesón claims that 'from an ethical standpoint governments are, internationally and domestically, mere agents of people. Consequently, their international rights derive from the rights of individuals who inhabit and constitute the state' (Tesón, 1996). For Tesón, the reason for creating and maintaining states is to ensure the protection of 'natural' rights of individuals. These 'natural rights' are also called 'fundamental' or 'human rights' (Finnis, 1980). The phrase 'human rights' is used to refer to 'natural rights' or to 'international human rights law' which is used as a taxonomy of rights for societies lacking a domestic bill of rights to emulate (Buchanan, 2013). The two problems with military intervention in a state on the grounds of human rights violations are that some states, including the United States, acknowledge the supremacy of international human rights law undermines constitutional democracy and that international human rights law is not produced by democratic processes. The other problem is the cultural critique: that the moral values underpinning international human rights law are based on Graeco - Roman philosophy and Judaeo - Christian theology, and are alien to the Asian values which are based on order, discipline and loyalty, rather than on liberty and freedom (the Lee Kuan Yew thesis [Note 30]) (Sen, 1999). But arising from the limited and broad interventionism theses are two doctrines: the doctrine of pro-democratic intervention and 'responsibility to protect' to which we now turn.

\subsection{Pro-Democratic Intervention}

There has been a concerted attempt to redefine sovereignty. Political sovereignty is the right to rule over a delimited territory and the population residing in it. The world order can be traced to the Westphalian Peace when, after thirty years' bloody wars, in 1648 sovereignty was vested in states and sovereign states exist in horizontal relationship of equality (Kissinger, 2015).

Exponents of pro-democratic intervention argue that pro-democratic intervention is compatible with Articles 2(4) and 51 of the UN Charter. Reisman, the leading exponent, opines that the term 'sovereignty' is anachronistic when applied to undemocratic governments and leaders and should be replaced by 'popular sovereignty' vested in the individual citizens of a state. This means that unilateral intervention to support or restore democracy does not violate state sovereignty. The argument goes thus that the Chinese Government's massacre in Tiananmen Square to maintain an oligarchy against the wishes of China was a violation of Chinese sovereignty (Reisman, 1990). What Reisman did not realise was that if the students had won at Tiananmen Square they would have been rejected by over 900 million Chinese peasants (O’Brien, 1989). Apart from this political consideration, Kissinger in On China noted the unintended consequence of attempting to alter the domestic structure of a country of the magnitude of China from outside and acknowledged that 'Western concepts of human rights and individual liberties may not be directly translatable, in a finite period of time geared to Western political and news cycles, to a civilisation for millennia ordered around different concepts' (Kissinger, 2011).

The two interventions cited by exponents of pro-democratic intervention are Grenada (1983) and Panama (1989) - discussed above - which are highly dubious (D’Amato, 1990, Reisman, 1990). Another dubious pro-democratic intervention is the Tanzania intervention in Uganda (1979).

In April 1979, the brutal rule of President Idi Amin came to an end as a result of his overthrow by Tanzanian troops. Humanitarian considerations played an important role. Tanzania intervention was hailed by some scholars as an act of liberation (Tesón, 1996) but rejected by others as a precedent supporting the legality of humanitarian intervention (Cassese, 2005). Cassese's rejection of the Tanzania - Uganda case as an authoritative precedent for humanitarian intervention is supported by two arguments. The first is that Tanzania never relied on humanitarian reasons. President Julius Nyerere of Tanzania declared that while it was his responsibility to overthrow the Ugandan President, he had the 'right' to overthrow Amin because Amin's government was a government of thugs. The second reason is that Tanzania relied on the concept of 'two wars' (Amin's troops invading the Tanzanian territory in October 1978 and the November 1 annexation of Tanzania's territory north of Kagera salient which was tantamount to war) coupled with self-defence considerations. Cassese argues that the UN Charter does not authorise individual states to use force against other states with a view to stopping atrocities, and that such use of force may only be resorted to when the Security Council considers that it is exceptionally justified and authorises it' (Cassese, 2005).

\subsection{Responsibility to Protect (R2P)}

We noted above the use of 'popular sovereignty' as a justification for pro-democratic intervention in Tanzania Uganda (1979), Grenada (1983) and Panama (1989). In 1994, the intervention was too late or slow to halt the murder of 800,000 people in Rwanda. In 1989, the North Atlantic Treaty Organisation waged war in Kosovo to stop ethnic cleansing. In both cases the Security Council failed to authorise the use of force to protect vulnerable 
populations. Security Council's vacillation on Kosovo was the driving force for the establishment of the International Commission on Intervention and State Sovereignty (ICISS) to look into the problem of humanitarian intervention and state sovereignty with a view to finding a political consensus on the use of force to support humanitarian interventions.

Cutting away the frills, the ICISS 2001 Report, The Responsibility to Protect, also known as 'R2P', stated:

- There is no better or more appropriate body than the United Nations Security Council to authorise military intervention for humanitarian purposes.

- Security Council's authorisation must be sought prior to military intervention.

- Security Council should deal promptly with any request for authorisation of military action.

- The Permanent Five members of the Security Council should agree not to apply their veto power where vital state interests are not involved.

- If the Security Council rejects a proposal or fails to deal with it in a reasonable time, alternative options are: consideration by the General Assembly in Emergency Special Session under the 'Uniting for Peace' procedure; and action within area by regional or sub-organisations under Chapter VIII of the UN Charter, subject to their seeking subsequent authorisation from the Security Council.

- The Security Council must take cognisance of the fact that if it fails to act in conscience-shocking situations, concerned states may not rule out other means of dealing with the situation (ICISS, 2001).

The problem with the above guidelines is that it has the potential to divide the world into 'civilised' and 'uncivilised' (a return to pre-Enlightenment philosophy alluded to above) and to promote a return to colonial practice. Powerful states can determine whose human rights justify departing from the principle of non-intervention. Responsibility to protect has been described as a euphemism for US hegemony (Weiss, 2015).

The UN World Summit of September 2005 which adopted the 'responsibility to protect' rejected the claim of NATO powers that, as a regional group of democratic governments, they had the right to use force in alleged protection of human rights and reaffirmed the authority of the Security Council to mandate coercive action to maintain peace and security. Finally, the Summit endorsed the conclusions of a December 2004 UN Panel, which included many prominent Western figures, that (i) the principles of the Charter concerning the use of force can be lawfully deployed only when authorised by the Security Council or in defence against an armed attack under Article 51 of the UN Charter, and (ii) that Article 51 of the Charter needs neither extension nor restriction (Chomsky, 2008).

\section{The Bush Doctrine}

The genesis of the Bush Doctrine could be traced to two important statements in 2002. In the first, President G W Bush, Jnr. proffered a broad doctrine of self-defence in his January 2002 State of the Union address where he declared that the greatest danger to America lay where terrorism, rogue states and weapons of mass destruction intersected and that there was an 'axis of evil' consisting of Iran, North Korea and Iraq (Note 31).

Hitherto, some have claimed that the prohibition of the 'threat or use of force' contained in Article 2(4) of the UN Charter was dead. But it is clear that it remains today since states do not freely break this prohibition without justifying their action. Self-defence has been restricted to when an 'armed attack occurs'.

At the beginning of June 2002 President Bush claimed that 'those who harbour terrorists are as guilty as terrorists themselves and must be treated accordingly by bombing and invasion' (Bush, 2010), a position which unilaterally revokes the sovereignty of those states. In September 2002, the National Strategy of the United States of America stated: 'We must adapt the concept of imminent threat to the capabilities and objectives of today's adversaries' (Note 32).

It appears that President Bush in his West Point speech was preparing for the armed intervention in Iraq by suggesting that Iraq had one of 'the unbalanced dictators with weapons of mass destruction' (Bush, 2010). The way seemed to be paved for a pre-emptive strike by the US and the UK on 8 November 2002 when the Security Council adopted Resolution 1441 which deemed Iraq to be in 'material breach' of the ceasefire resolution adopted at the end of the Gulf War in 1991, and such breach was considered a 'threat to international peace and security'. However, Resolution 1441 did not expressly authorise the use of force against Iraq and a further resolution providing the express authorisation was not adopted. And yet, on 19 March 2003, the "coalition of the willing' decided the time was right to attack Iraq.

The Bush Doctrine of anticipatory self-defence or pre-emptive use of force raises two questions (Paul, 2004). 
The first is whether it is consistent with the inherent right of self-defence under Article 51 of the UN Charter.

Proponents of the Bush Doctrine rely on the Caroline case. That line of argument has been shown to be a subterfuge (see section 3.2 above). Could the intervention in Iraq be justified by unilateral proxy? D'Amato argues that if Israel had no 'self-defence' justification and 'no state of war entitlement', then unilateral proxy used as a justification in bombing the Osiraq reactor in 1981 could apply to quite different areas of humanitarian intervention such as the US interventions in Grenada and Panama when human rights were in jeopardy and the international community for whatever reasons did not take action (D'Amato, 1996). The fact is that this would be a spurious argument because the argument that weapons of mass destruction presented a threat to the US became vacuous when no such weapon could be found.

The second question is whether a new rule of customary international law is created. The answer is in the negative because there is no evidence of a clear intention to accept invasion of Iraq in 2003 by what the Bush Administration calls "the coalition of the willing" as representing a new norm of anticipatory self-defence. Only one fifth of the 191 member states of the United Nations expressed their support for the invasion of Iraq in 2003(Paul,2004). (There are now 193 member states of the United Nations; South Sudan being the $193^{\text {rd }}$ member state joined in 2011 .) Even if Iraq War (2003) creates a new norm of customary international law, such a norm cannot modify or abrogate the United States obligation to comply with Article 2(4) of the UN Charter.

\section{Conclusions}

The origins of the doctrines of protection of nationals abroad and humanitarian intervention, which came into use in the nineteenth century, have been traced to the Western idea of just war formulated by Ambrose, Augustine and Aquinas. In spite of Articles 2(4) and 51 of the UN Charter which regulate the use of force in international law, most of the themes in contemporary debates on humanitarian intervention are based on the just war idea: the moral impetus to support the oppressed, restore democracy, responsibility to protect, and not allowing evil to prevail over good. However, the just war idea does not yield unambiguous answers to question on humanitarian interventions.

Three US humanitarian interventions in the Western hemisphere - Dominican Republic (1965), Grenada (1983) and Panama (1989) - are highly dubious. The Suez Canal Crisis (1956) was a post-colonial adventure, the two interventions in the Congo (1960 and 1964) were at best interventions to protect nationals abroad and secure access to mineral resources, and the paramilitary activities in the Congo from 1996 to 1998 were brazen exploitation of the mineral resources of Congo by its neighbours, Rwanda and Uganda.

The claim that one state may enforce the rights of subjects in another state based on 'popular sovereignty' and the so-called 'pro-democratic intervention' are regarded with suspicion for two reasons. First, the resurrection of the pre-Enlightenment philosophy that categorises people as either 'civilised' or 'uncivilised' - the former entitled to sovereignty and the latter not entitled and subject to the will of foreign powers is now presented as 'sovereignty as responsibility' (Ayoob, 2002). The second is that the term 'democracy', the subject of pro-democratic intervention, has been around since Ancient Athens but did not become institutionalised anywhere until the end of the eighteenth century and full legal enfranchisement had to wait in the United States until the nineteenth century (Fukyuama, 2014). Democracy means different things to different people - it means 'liberal' (Western democracy) or illiberal or ballot box democracy - and it has been used at different times for different purposes. While it is used as an adjunct to other justifications for humanitarian intervention (in Grenada, Panama and Iraq (2003)), it has also been used to undermine the international rule of law by the United States' justification of non-ratification of the Rome Treaty that established the International Criminal Court (Casey, 2001 - 2002). The idea, after the Cold War, that democracy could be globalised and that the outbreak of Arab Spring of 2011 suggested the start of a wave of democratisation in the Middle East are ruling illusions: Islam or Arab culture has been resistant to democracy and five years into the Arab Spring, with the possible exception of Tunisia, the predictions that Arab societies will not be able to sustain democracy may be correct. As Kissinger observes in World Order:

"Those committed to democratisation have found it difficult to discover leaders who recognise the importance of democracy other than as means to achieve their own ends' (Note 33).

Kissinger adds that overwhelming majority of contestants are embroiled in conflicts in furtherance of their geostrategic and georeligious interests and do not perceive them as 'between a dictator and the forces of democracy but between ... contending sects and their regional backers' (Note 34).

The Bush Doctrine is a reading of the UN Charter that would allow a state to invade another state just because the target state has a less than democratic government. The Bush Doctrine as a non-reciprocal rule that the US 
alone can prevent war by attacking states that are developing weapons of mass destruction or act where the UN Security Council is unwilling or too late to intervene is simply a unilateral assertion of power which is subject to arbitrariness and leaves weak states at the mercy of powerful states. Put differently, it is 'might' that counts and not 'right' under international law.

Finally, adherents of the unilateral proxy to allow one state to invade another on behalf of the international community - Western scholars such as D'Amato and Reisman but not Franck - ignore the fact that the position that the United States must protect the neoliberal states and the 'free' world must be considered conjunctively with the transition of hegemony from West to East. This poses a choice to the United States either to manage the transition peacefully or through a military confrontation. That nationalist sentiments can be rallied in support of the doctrine of pre-emptive strike is well-tested in Iraq (2003). However, 'America', as Sachs shrewdly observes, 'will not again dominate the world economy or geopolitics as it did in the aftermath of World War II' (Sachs, 2011), and, what is more, the debate on the legality of military intervention by powerful states to protect their nationals abroad or install a 'legitimate' regime in a weak state will not go away in a hurry.

\section{Acknowledgements}

A version of this paper was presented on $27^{\text {th }}$ April 2016 at the author's Archbishop Desmond Tutu Centre for War and Peace Studies Lecture at Liverpool Hope University, United Kingdom. I thank those present for their comments. Thanks also to the anonymous referees for their informed and constructive comments.

\section{References}

Arendt, H. (1963). Eichmann and the Holocaust. London: Penguin Books.

Ayoob, M. (2002). Humanitarian Intervention and State Sovereignty. The International Journal of Human Rights, 6(1), 81-102. http://dx.doi.org/10.1080/714003751

Brownlie, I. (1963). International Law and the Use of Force by States. Oxford: Clarendon Press. http://dx.doi.org/10.1093/acprof:oso/9780198251583.001.0001

Buchanan, A. (2013). The Heart of Human Rights. Oxford: Oxford University Press. http://dx.doi.org/10.1093/acprof:oso/9780199325382.001.0001

Bush, G. W. (2010). Decision Points. London: Virgin Books.

Casey, L. A. (2001-2002). The Case Against the International Criminal Court. Fordham International Law Journal, 25, 840-872.

Cassese, A. (2005). International Law (2nd ed., pp. 373-374). Oxford: Oxford University Press.

Chesterman, S. (2001). Just War or Just Peace? Humanitarian Intervention and International Law (pp. 45-87). Oxford: Oxford University Press.

Chomsky, N. (2008). Humanitarian Imperialism: The New Doctrine of Imperial Right. Monthly Review, 1-33. Retrieved

from http://monthlyreview.org/2008/09/01/humanitarian-imperialism-the-new-doctrine-of-imperial-right

Corten, O. (2012). The Law Against War: The Prohibition of the Use of Force in Contemporary International Law. Oxford: Hart Publishing.

D'Amato, A. (1990). The Invasion of Panama Was a Lawful Response to Tyranny. American Journal of International Law, 84, 516, 518. http://dx.doi.org/10.2307/2203464

D’Amato, A. (1996). Israel's Air Strike Against the Osiraq Reactor: A Retrospective. Temple International and Comparative Law Journal, 10, 259-264.

Finnis, J. (1980). Natural Law and Natural Rights (pp. 198-230). Oxford: Clarendon Press.

Franck, T. M. (2003). What Happens Now? The United Nations After Iraq, American Journal of International Law, 97, 607-620. http://dx.doi.org/10.2307/3109846

Fukuyama, F. (2014). Political Order and Political Decay: From the Industrial Revolution to the Globalisation of Democracy (pp. 399-428). London: Profile Books.

Henkin, L. (1991). The Invasion of Panama Under International Law: A Gross Violation. Columbia Journal of International Law, 29, 293-317.

Higgins, R. (1995). Problems and Process: International Law and How to Use it (pp. 240-244). Oxford: Clarendon Press. http://dx.doi.org/10.1093/law/9780198764106.001.0001 
Holzgrefe, J. L., \& Keohane, R. O. (2003). Humanitarian Intervention: Ethical and Political Dimensions. Cambridge: Cambridge University Press. http://dx.doi.org/10.1017/CBO9780511494000

ICISS. (2001). The Responsibility to Protect, Report of the International Commission on Intervention and State Sovereignty, (pp. xii-xiii) Ottawa, Canada. The International Development Research Centre. Retrieved from http://www.idrc.ca

Jennings, R. Y. (1938). The Caroline and McLeod Cases. American Journal of International Law, 32(1), 82-99. http://dx.doi.org/10.2307/2190632

Kissinger, H. (2011). On China (pp. 426-427). London: Allen Lane.

Kissinger, H. (2015). World Order: Reflections on the Character of Nations and the Course of History. London: Penguin.

Kyle, K. (1992). Suez. London: Weidenfeld and Nicolson.

Lillich, R. B. (1967). Forcible Self-Help by States to Protect Human Rights. Iowa Law Review, 53, 325-51.

Lillich, R. B. (1992). Forcible Protection of Nationals Abroad. Dickinson Law review, 104(3), 439-469.

Locke, J. (1946). In J. W. Gough (Ed.), The Second Treatise of Civil Government and a Letter Concerning Toleration. Oxford: Blackwell.

Mantz, J. M. (2008). Improvisational economics: Coltan production in the eastern Congo. Social Anthropology, 18(1), 34-50. http://dx.doi.org/10.1111/j1469-8676

McNemar, D. W. (1971). The Post-independence War in the Congo. In R. A. Falk (Ed.), The International Law of Civil Wars. Baltimore: The John Hopkins Press.

Merston, G. (1988). Armed Intervention in the Suez Canal Crisis: The Legal Advice. International and Comparative Law Quarterly, 37, 773-817.

O'Brien, C. C. (1989, June 27). Where Deng scores over democracy. The Times (UK).

Oppenheim, L. F. L. (1952). In H. Lauterpacht (Ed.), International Law (7th ed., Vol. 2, p. 154). London: Longmans.

Paul, J. R. (2004). The Bush Doctrine: Making or Breaking Customary International Law. Hastings International and Comparative Law Review, 27, 457-479.

Pearson, J. (2003). Sir Anthony Eden and the Suez Crisis: Reluctant Gamble. Basingstoke: Palgrave Macmillan. http://dx.doi.org/10.1057/9780230512597

Reisman, W. M. (1990). Sovereignty and Human Rights in Contemporary International Law. American Journal of International Law, 84, 866-876. http://dx.doi.org/10.2307/2202838

Ruys, T. (2010). 'Armed Attack' and Article 51 of the UN Charter (pp. 271-272). Cambridge: Cambridge University Press. http://dx.doi.org/10.1017/CBO9780511779527

Sachs, J. (2011). The Price of Civilisation: Economics and Ethics after the Fall (p. 262). London: The Bodley Head.

Sen, A. (1999). Development as Freedom (p. 231). Oxford: Oxford University Press.

Smith, J. H. (2011). Tantalus in the Digital Age: Coltan Ore, Temporal Dispossession and 'movement' in the Eastern Democratic Republic of Congo. The American Ethnologist, 38(1), 17-35. http://dx.doi.org.10.1111/j.1548.1425.2010.01289.x

Tesón, F. R. (1996). Humanitarian Intervention: An Inquiry into Law and Morality (2nd ed.). Irvington - on Hudson, New York: Transnational Publishers.

Turner, T. (2013). Congo (pp. 15-26). Cambridge: Polity.

Vattel, E. (1811). The Law of Nations, or Principles of the Law of Nature, Applied to the Conduct of Nations and Sovereigns (4th ed.). London: W. Clarke \& Sons.

Waldock, H. (1952). The Regulation of the Use of Force by Individual States in International Law, In Recueil des Cours (RdC), (pp. 455, 466 - 7), Vol. 2, Hague Academy of International Law. http://dx.doi.org/10.1163/ej.9789028611825.451-517

Weiss, T. G. (2015). Humanitarian Intervention. Cambridge: Polity.

Wingfield, T. C. (2000). Forcible Protection of Nationals Abroad. Dickinson Law Review, 104(3), 439-469. 
Wingfield, T. C., \& Meyen, J. C. (Eds.). (2002). Lillich on the Forcible Protection of Nationals Abroad (pp. 41-95). Newport Rhode Island: Naval War College.

\section{Notes}

Note 1. See Locke (1946: 5 and 15).

Note 2. Wingfield (2000: 41), Holzgrefe and Keohane (2003: 18), and Weiss (2015: 14-15).

Note 3. See the intervention of England, France and Russia in Greece in 1827 to stop Turkish massacre of populations associated with insurgents and France's intervention in Syria in 1860 to protect Maronite Christians.

Note 4. See Chesterman (2001: 8-9).

Note 5. See Chesterman (2001: 12).

Note 6. See Chesterman (2001: 17).

Note 7. See Vattel (1811, 162-163).

Note 8. (1996) ICJ Rep 226, para. 47.

Note 9. (1986) ICJ Rep 14-150, at para. 199.

Note 10. Case concerning oil platforms (Islamic Republic of Iran v United States of America) (2003) ICJ Rep 161-219.

Note 11. Ibid., para. 51.

Note 12. Ibid., para. 125.

Note 13. See Brownlie (1963: 338-9).

Note 14. Corfu Channel case (Merits) (United Kingdom v Albania) (1949) ICJ Rep 4-38.

Note 15. Ibid., p. 35.

Note 16. See Brownlie (1963: 267-8).

Note 17. See Jennings (1938: 82).

Note 18. See D'Amato (1996: 261).

Note 19. See Brownlie (1963: 289).

Note 20. See Jennings (1938: 91).

Note 21. See Kyle (1992: 385).

Note 22. The events that led to the Suez Crisis of 1956, the invasion of Egypt by British, French and Israeli forces, and the cessation of hostilities are critically assessed in Kyle (1992) and Pearson (2003).

Note 23. (2005) ICJ Rep 168-283.

Note 24. Ibid., para. 147.

Note 25. Ibid., para. 250.

Note 26. See Higgins (1995: 246).

Note 27. (1979) ICJ Rep 1-23.

Note 28. See Henkin (1991: 302).

Note 29. Supra, note 21.

Note 30. Lee Kuan Yew was a former Prime Minister of Singapore.

Note 31. State of Union Address - 29 January 2002 at http://whitehouse.gov/news/releases/2002/01/20020129-11.html

Note 32. National Security Strategy of the United States of America, 20 September 2002, available at http://www.whitehouse.gov.nsc.nss.pdf

Note 33. See Kissinger (2015: 123).

Note 34. See Kissinger (2015: 127).

Note 35. See Franck (2003: 607-620). 


\section{Copyrights}

Copyright for this article is retained by the author(s), with first publication rights granted to the journal.

This is an open-access article distributed under the terms and conditions of the Creative Commons Attribution license (http://creativecommons.org/licenses/by/4.0/). 